\title{
Correction to: Alternative estimation approaches for the factor augmented panel data model with small $T$
}

\author{
Jörg Breitung ${ }^{1} \cdot$ Philipp Hansen ${ }^{1}$
}

Published online: 14 June 2021

(C) The Author(s) 2021

\section{Correction to: Empirical Economics (2021) 60:327-351 https://doi.org/10.1007/s00181-020-01948-7}

The article Alternative estimation approaches for the factor augmented panel data model with small $T$, written by Jörg Breitung and Philipp Hansen, was originally published Online First without Open Access. After publication in volume 60, issue 1, pages 327-351, the author decided to opt for Open Choice and to make the article an Open Access publication. Therefore, the copyright of the article has been changed to $\odot$ The Author(s) 2021, and the article is forthwith distributed under the terms of the Creative Commons Attribution 4.0 International License, which permits use, sharing, adaptation, distribution and reproduction in any medium or format, as long as you give appropriate credit to the original author(s) and the source, provide a link to the Creative Commons licence, and indicate if changes were made. The images or other third party material in this article is included in the article's Creative Commons licence, unless indicated otherwise in a credit line to the material. If material is not included in the article's Creative Commons licence and your intended use is not permitted by statutory regulation or exceeds the permitted use, you will need to obtain permission directly from the copyright holder. To view a copy of this licence, visit http://creativecommons.org/licenses/by/4.0. Open access funding enabled and organized by Projekt DEAL.

The original article has been corrected.

Open Access This article is licensed under a Creative Commons Attribution 4.0 International License, which permits use, sharing, adaptation, distribution and reproduction in any medium or format, as long as you give appropriate credit to the original author(s) and the source, provide a link to the Creative Commons licence, and indicate if changes were made. The images or other third party material in this article are included in the article's Creative Commons licence, unless indicated otherwise in a credit line to the

The original article can be found online at https://doi.org/10.1007/s00181-020-01948-7.

Jörg Breitung

breitung@statistik.uni-koeln.de

1 Institute of Econometrics, University of Cologne, Albertus Magnus Platz, 50923 Köln, Germany 
material. If material is not included in the article's Creative Commons licence and your intended use is not permitted by statutory regulation or exceeds the permitted use, you will need to obtain permission directly from the copyright holder. To view a copy of this licence, visit http://creativecommons.org/licen ses/by/4.0/.

Publisher's Note Springer Nature remains neutral with regard to jurisdictional claims in published maps and institutional affiliations. 